\title{
Exploring Portfolios in the Elementary Classroom with Students with Disabilities/Exceptionalities: Timely or Time-consuming?
}

\author{
S. Anthony Thompson \\ University of Regina \\ Lynsey Baumgartner \\ Regina Catholic School Division
}

\begin{abstract}
In the inclusive/special education literature, practitioners often claim that using portfolios is excessively time-intensive, while other researchers lay claim to positive possibilities for students with disabilities/exceptionalities, such as increased self-esteem, internal locus of control, choice-making, and active participation in learning. To explore both the time-consuming charge and the positive possibilities associated with portfolio use, we conducted a case study with students with disabilities/exceptionalities and some labelled at-risk in the second author's elementary classroom. Data sources included a research journal, general classroom observations, and structured student interviews. We found that the teacher identified more examples of positive outcomes than did her students and that implementing portfolios can indeed be a protracted process. We theorize about these findings and offer some concluding suggestions to mitigate labour intensity to better support students with disabilities/exceptionalities.
\end{abstract}

\section{General Purpose: Exploring Portfolios in the Elementary Classroom}

Portfolio use in the elementary classroom may be one of the au courant topics in inclusive/special education (Salvia, Ysseldyke, \& Bolt, 2006). Although diverse in appearance and content, portfolios are generally characterized as a purposeful and meaningful collection of artifacts that may serve as evidence that students have met particular standards or that they are developing in identified skill areas. Almost anything may constitute an artifact, including worksheets, snippets from transcribed interviews, student videos, art projects, self-monitoring checklists, and metacognitive tools. Portfolios may be thought of as evolving learning composites that attempt to capture students' learning in holistic, varied, and important ways (Carothers 
\& Taylor, 2003; Cole, Struyk, Kinder, Sheehan, \& Kish, 1997; Denham \& Lahm, 2001). Ideally, artifacts are selected that exemplify learning as both performance and process, and preferably, students are active partners in portfolio construction and artifact reflection. Because of their popularity and apparent facility, our purpose of this study was to investigate portfolio use in an elementary classroom from the dual perspectives of a classroom teacher and students with disabilities/exceptionalities.

Portfolios within inclusive/special education. To reiterate, portfolios may be varied in content and intent; they are individualized, distinctive and richly descriptive. Often they connote thoroughness and creativity - perhaps a throwback to the fine arts world - so their appeal to inclusive/special educators may not be surprising. Consider the varieties in the inclusive/special education literature. Showcase portfolios (Carothers \& Taylor, 2003; Duffy, Jones, \& Thomas, 1999) highlight collections of students' commendable work and may be used as a tool to advertise students' exemplary projects, perhaps to gain access to unique programs or institutions. Cumulative portfolios, also referred to as everything portfolios, (Carothers \& Taylor, 2003; Duffy et al., 1999) contain items collected over time and may include projects in progress as well as those in final form. Such compilations may be analyzed to think through the ways in which students' learning shifts. Process portfolios call attention to the stages or steps to assignmentswhat is at issue is how students are continually (re)constructing knowledge, as opposed to completed coursework (Carothers \& Taylor, 2003; Salend, 1998). Educators may structure portfolios around pre-selected goals and/or objectives, usually derived from team planning meetings. These portfolios are often used to document progress toward Individual Education Plan (IEP) goals (Carothers \& Taylor, 2003; Salend, 1998). Such goal-based portfolios are similar to product portfolios (Duffy et al., 1999), where students are provided with a table of contents that delineates required topics or products. Students include work samples in each of these areas. Of course, many portfolios are amalgams of these assorted types.

Indeed, the use of portfolios has appeared to proliferate lately within inclusive/special education, perhaps due to federal legislation in the United States-notably No Child Left Behind and Individuals with Disabilities Education Act. Portfolios have been used within the context of students with significant cognitive disabilities (Hager \& Slocum, 2005; Kleinert, Kearns, Farmer, \& Kennedy, 1997), students with Autism Spectrum Disorder (Carothers \& Taylor, 2003), students with other developmental disabilities (Denham \& Lahm, 2001; Hager \& Slocum, 2005; Walter-Thomas \& Brownell, 2001; Ysseldyke \& Olsen, 1999), as well as students labeled generally at-risk (Carpenter-Aeby \& Kurtz, 2000). Farr (2003) provided useful guidelines for constructing portfolios in the area of reading thought to be useful for students with reading difficulties and/or disabilities. Denham and Lahm (2001) considered ways and means of using technology to support students with moderate and severe disabilities to construct their own portfolios. Portfolios have also been used with students with learning disabilities (Cole et al., 1997); interestingly, in that study Cole et al. combined portfolio assessment with cognitive strategy instruction.

Portfolios: The promise of positive possibilities. If there were only thread weaving through the tapestry of the portfolio literature and students with disabilities/exceptionalities, it might be remarkably uplifting. For example, Ezell, Klein, and Ezell-Powell (1999) found that "All teachers and parents agreed that [the use of portfolios] increased the students' selfesteem...Parents and teachers expressed that students [with intellectual disabilities] experienced a feeling of empowerment because of their involvement in the portfolio assessment process" (p. 
459). Carpenter-Aeby and Kurtz's (2000) study, in which students in a "last-chance" alternate school were given an opportunity to create a new life narrative, provides another powerful portfolio example as a vehicle to promote positive changes in students' lives:

The process of creating a portfolio [brought] forth the problem-saturated story and eventually open[ed] up new possibilities [to] reveal strengths for chronically disruptive students and their families. The portfolios serve[d] to document and validate the change from disruptive to responsible student. (p. 219)

Relatedly, Ezell and Klein (2003) promoted an internal locus of control for students with intellectual disabilities through portfolios. Ezell et al. (1999) supported self-advocacy for students with intellectual disabilities through portfolios.

Positive changes may manifest in other ways - ways more directly associated with learning. Portfolios have been shown to promote student reflectivity and may be structured to assist students to self-monitor, self-evaluate, and generalize skills (Carothers \& Taylor, 2003; Cole et al., 1997; Duffy et al., 1999; Ezell \& Klein, 2003; Ezell et al., 1999; Hager \& Slocum, 2005; Kleinert, Green, Hurte, Clayton, \& Oetinger, 2002; Walter-Thomas \& Brownell, 2001). Battle, Dickens-Wright, and Murphy (1998) and Ezell et al., (1999, p. 453) have used portfolios to "foster self-determination skills" for students with disabilities/exceptionalities. In each of these examples, variations of reflective portfolios were used (Carothers \& Taylor, 2003; Salend, 1998; Thompson, 2007). Through reflective portfolios, students are supported to consider aspects of their learning, such as effort expended, strategy use, and feelings. To encourage students to ponder, Salend (1998) recommended the use of caption statements, which are "concise, written comments in which students and teachers note the item and the date, establish the context in which the student developed the item, and outline the reasons why the student or teacher included the piece in the portfolio" (p. 39).

Portfolios: Implementation concerns. Of course there is never just one thread in a story-no matter how uplifting; unfortunately, the other narrative strands about the uses of portfolios are a little more worn, a little less inspiring. Some, particularly practitioners, criticize portfolios for being time and labour intensive: "Teachers expressed frustration with the amount of time required to complete student assessment portfolios" (Kleinert, Kennedy, Kearns, \& Farmer, 1999, p. 93; see also Kampfer, Horvath, \& Kleinert, 2001). Again in 2002, Kleinert et al. reported that some teachers were concerned about "the amount of time required to complete alternate assessment[s];" a percentage of teachers sampled claimed that "completing portfolios for students with severe disabilities took time away from teaching" (p. 40). Daniels (1999) concurred, "a major drawback of portfolio assessment is the issue of teacher time. Teachers must restructure their time to...develop record-keeping systems that are time-efficient and meaningful" (p. 172). Gelfer and Perkins (1998) agreed as well, claiming that "the portfolio as an evaluation tool can be time consuming" (p. 46). Finally, Carpenter-Aeby and Kurtz (2000) also recognized that "the preparation, development and supervision of students' portfolios can be daunting” (p. 227).

\section{Limitations of Portfolio Research}

Part of the larger research conversation around the use of portfolios includes somewhat conflicting notions: the reported positive possibilities of using portfolios with students with dis- 
abilities/exceptionalities on the one hand and the very real teacher concern over their time and labour intensity on the other. Given this conundrum, it seems more than ironic that there are few researchers that have actually interviewed students of any description and even fewer that have specifically interviewed students with disabilities/exceptionalities to see if these heartening hopes claimed by portfolio investigators are realized. Let us be clear: Most researchers constrain their investigations by interviewing teachers only. For example, in the Ezell et al. (1999) study, where, ironically, student empowerment was the research focus, "no formal guided interviews were conducted [with students]" (p. 457) despite teacher generated data forming a significant part of the findings. In 2003, Ezell and Klein explored locus of control, students with intellectual disabilities, and portfolio assessment, but they too did not interview students. Battle et al. (1998) suggested that portfolios may be helpful to support student self-advocacy and ManningKratcoski (1998) provided guidelines for using portfolios; however, neither researcher spoke with students.

When researchers do interview students they often limit their data to neurotypical or nondisabled students, such as Watson-Barnett (1997) who conducted a year long portfolio project in a first grade classroom, but included conversations with typical students only. Hardin and Cook (2001) taught high school students to develop a portfolio as a way to assist with their career planning. Although they interviewed students, again, there were none conducted with students with disabilities/exceptionalities. Carpenter-Aeby and Kurtz (2000) vigorously argued for the portfolio as a strength-based intervention for students at-risk that did include a few peppered quotes from pupils, although student responses were not prominent. We did locate one published, refereed study where the researchers, namely, Young, Mathews, Kietzmann, and Westerfield (1997) interviewed students labelled at-risk as part of a portfolio process (and concomitantly the research project); they found that a conference, a conversation with a student in the presence of their portfolio, can afford opportunities to "develop a personal relationship with the teacher" ( $p$. 348). Except for these few examples, there are hardly any studies that document aspects of portfolio use from the perspective of students with disabilities/exceptionalities, and we know of none that do so while at the same time documenting a teacher's perspective, specifically in reference to time and labour intensity. As stated, this simultaneity became the purpose of our study.

\section{Detailed Purpose and Research Questions}

Our general purpose was to explore the use of portfolios in an elementary classroom from the dual perspectives of the students with disabilities/exceptionalities, and of the teacher, the second author. Specifically, we were interested in traversing the everyday lived tapestry of using portfolios. As a teacher educator (first author) and a teacher (second author), we were concerned about the kinds of time and labour investment portfolios seem to require, issues of efficiency within the everyday classroom. At the same time, we wanted to know first hand what students thought about their portfolios. We asked students to reflect upon what and how they learned, the challenges they faced, and how they felt about their accomplishments. To be specific, we had two inter-related research questions:

1. From the perspective of a teacher, how efficient are portfolios to use in the classroom; specifically, how much labour and time commitment is required within the everyday classroom routines to implement portfolios? 
2a. Would students with disabilities/exceptionalities report experiencing the much-cited positive aspects about their own portfolios?

2b. How might such students reflect upon learning activities within their own portfolios?

\section{Methodology}

To answer these questions, we conducted an exploratory qualitative case study. A case study is an extraordinarily versatile research methodology (see McCormick, 2000, for example) and has been lauded for its practical nature within education (Merriam, 1998), notably so within inclusive/special education (Ghesquière, Maes, \& Vandenberghe, 2004). Although the case study is varied, its essential common feature may be its bounded nature (Stake, 1995); case study researchers must clearly articulate what is and what is not within the research project purview. We conducted this research from February 2005 until June 2005 in the second author's elementary school classroom, and hence, it is framed within that time by the constellation of student participants, by ourselves as researchers, and by the two teaching assistants. Case study research often presents a comprehensive, holistic picture of the issue of interest, frequently soliciting multiple points of view and multiple data sources. A case study is the art (and science) of the particular (Stake, 1995).

Yet, our purpose was not simply descriptive, even though it is explicitly exploratory. Exploratory projects can take up under-researched or novel areas of inquiry; case study research protocols sometimes have been falsely characterized as useful only within preliminary phases before the "real" research gets underway (see Yin, 1994). As we have shown, there appears to have been little research conducted within a case study framework that documents the ongoing everyday use of portfolios in the classroom that focuses upon student responses - in this way, our research is indeed descriptive. However, Stake (1995) and Merriam (1998) suggested that case study research may go deeper than description if investigators contextualize findings within the theories of the issue of investigation. Such case study uses are referred to as instrumental, as articulated by Stake (1995), or as interpretive according to Merriam (1998). Since our plan was to discern implications of this project beyond its immediacy, to consider the relevancy of portfolio use to support positive possibilities for students with disabilities/exceptionalities while simultaneously considering issues of manageability for teachers, we consider this case study to be interpretative.

\section{Method}

From February 2005 until June 2005 we conducted this study in the second author's elementary school classroom. As a professor in inclusive/special education and a special education teacher, we regard our collaborative partnership within the tradition of teachers-as-researchers (Agosta, Graetz, Mastropieri, \& Scruggs, 2004; Babkie \& Provost, 2004). Also involved within the research were two teaching assistants whom were normally assigned to the multi-grade classroom.

Student participants. Eight students participated in this study, and approximately 14 students were in the classroom. Most students were in Grade 3, with 1 in Grade 2, and 1 in Grade 
4. All students completed a portfolio. We were unable to secure consent for 6 students for various reasons, mainly due to student and family transience. As noted in Table 1, there was some student movement during the data collection period; in the classroom there were students with specific diagnoses, students waiting to be assessed for particular diagnoses, and those at-risk due to life circumstances. Ethics approval was obtained through the university, the school board, and through all parents and/or legal guardians of each participating student.

\section{Procedure}

Portfolio curriculum. The classroom teacher structured the portfolios around the novel Stuart Little by E. B. White (1945/1973). Many kinds of learning activities were included in this theme: language arts activities, such as reading, writing a poem and a nursery rhyme, composing a story of what it might look like if one were in Stuart's house; science activities, such as researching facts about mice and constructing a mouse report; art activities, such as creating a model of Stuart's house with popsicle sticks and drawing pictures; and mathematics activities, such as graphing frequency of classmate responses to named favourite animals.

Data sources and context. The classroom was located in a medium-sized community school within a lower socio-economic status neighbourhood in a medium-sized Western Canadian city. As stated, Lynsey, the classroom teacher, taught approximately 14 elementary students, some with official learning and/or behavioural diagnoses and some at-risk. Based upon observations, the first author noted that the classroom was very busy and at times seemingly chaotic; membership appeared to be fluctuating. During data collection, there was even a Grade 6 student placed in the classroom for a while. Perhaps due to (or exacerbated by) the changing student membership and resource constraints, there were some behavioural issues to deal with in the classroom. On certain days, Lynsey had many commitments that required much of her time in order to support her students, such as meeting parents and relevant caregivers, social workers, and the principal. In short, there appeared to be countless demands placed upon the teacher.

Lynsey maintained a research journal throughout the data collection period. About two to three times per week, she recorded her reflections about the project, the workload, the impact on her students and teaching assistants as well as other related issues she deemed relevant. At the end of the data collection period, Lynsey produced a final reflection document in which she contemplated the overall use of portfolios within her classroom and organized her thoughts into two basic categories: (a) things I liked and (b) things I did not like. This file is separate from her daily reflections in the research journal and is useful as an additional piece of data. The first author conducted classroom observations once or twice per week and maintained notes from the visits.

One of the teaching assistants conducted semi-structured interviews with individual students, which were tape-recorded and professionally transcribed. The teaching assistant had a well-established relationship with the students: She was present during the data collection period - the construction of the portfolios. Students were interviewed during school hours in an adjoining room to the classroom, the research interview context, and each one lasted approximately 20-30 min. Every student had their portfolio in front of them and they were free to rifle through different artifacts. As acknowledged, Salend (1998) provided sample caption prompts to elicit information from students regarding their portfolios. He suggested a broad range of questions, including areas of improvement, feelings about specific learning activities or outcomes, 
Table 1

Description of Student Participants

\begin{tabular}{llll}
\hline Pseudonym Grade & \multicolumn{1}{c}{ Official Diagnosis } & \multicolumn{1}{c}{ Comments } \\
\hline Barry & 2 & $\begin{array}{l}\text { Attention Deficit Hyper } \\
\text { activity Disorder (ADHD) }\end{array}$ & Taking Ritalin at time of study. \\
Colin & 3 & $\begin{array}{l}\text { At the time of study being } \\
\text { screened for ADHD }\end{array}$ & \\
Kyle & 3 & Mild Intellectual Disability & Witnessed trauma previous year. \\
Leslie & 3 & None & $\begin{array}{l}\text { During study, residing in social services residence; } \\
\text { moved in with parent the following year. }\end{array}$ \\
Aaron & 3 & None & During study, living with extended family member. \\
Tim & 3 & None & $\begin{array}{l}\text { Being screened for Autism } \\
\text { Karl }\end{array}$ \\
Celeste & 4 & $\begin{array}{l}\text { Intermittent Explosive Post } \\
\text { Traumatic Stress Disorder }\end{array}$ & $\begin{array}{l}\text { Taking medication, Valproic Acid and Risperadol. } \\
\text { Student was new to classroom. }\end{array}$ \\
\hline & & &
\end{tabular}

special efforts made, IEP objectives, content areas, thematic units, projects, difficulties, and strategy use. Because most students were in Grade 3, we adapted Salend's caption statements and limited them to the following five areas only: (1) What did you learn? (2) What did you find the hardest/most difficult to do? (3) What did you improve upon? (4) How did you improve? (How did you get better at ?) and (5) How do you feel about your portfolio? We felt that the last three questions, prompting students to think about their progress and their feelings, may elicit information about the strengths and positive features often associated with the use of portfolios. All students were asked these questions in approximately the same way and order. Although we did not pilot these questions, we agreed with Salend (1998) that these seemed reasonable questions to ask students, particularly if part of the research agenda was to come to know students' perceptions regarding their own learning.

Considerations when interviewing students with disabilities/exceptionalities. As mentioned, one of the teaching assistants interviewed students individually during the first week of June 2005. Some students appeared conversant, although some required some prompts to elaborate upon responses. The interviewer also had to consider the kind of prompting which were impacted by students' diagnoses (or suspected diagnoses; see Stalker 1998, for example; Swain, Heyman, \& Gillman, 1998; Thompson, 2002). The conversation with Karl, who was on a waiting list to be assessed for Autism Spectrum Disorder, may be telling, even at times somewhat humorous. The interviewer asked, "What did you learn reading the book?" to which Karl replied, "that Stuart Little is a mouse." She needed to become more thoughtful, more specific, with her 
questions: "What did you learn while you were doing your portfolio?" When carefully prompted in more concrete ways Karl spoke plenty, his interview was one of the longest of all students.

Data analysis. Our data analysis was iterative from theories of portfolio use to data and back to theory. We structured our analysis around our two research questions and the five questions posed to students. The first author coded all the students' transcripts, the teacher's research journal, and the final reflection document. Although a necessary part of the research, the observations provided more of the descriptive backdrop for the first author to become familiar with the daily classroom routines. The first author read through the student transcripts and the teacher's journal in their entirety several times, and then began coding. Using all the sources, data was initially coded based upon specific sections that spoke to the interview questions. Some of the initial codes used were "student fun," "time and effort," "dictionary-use," "improvement," "stuff learned," "feeling good," "feeling proud," and "unsure." Also, within the student transcript data certain responses were particularly descriptive, which were noted. Codes were organized into the themes, which, as noted, we chose to organize around our research questions. The second author was presented with the findings and given the opportunity to provide input into the findings, and agreed with the interpretations.

\section{Portfolios in Context: Their Use in the Ongoing Classroom Routine}

Before we address the two research questions, we provide an overview of the ongoing classroom routines as related to the use of portfolios or how portfolios were used by the classroom teacher. As portfolios by their nature are ongoing, organic, and comprehensive, they provided daily feedback to Lynsey to consider making curricular and instructional adjustments. In the following research journal excerpt, for example, Lynsey changed how she instructed a writing assignment:

Later on during the day, I checked each students' [note]books. I was not able to read their printing, and therefore could not read their assignments. I decided to re-copy students' [comprehension] questions into their notebooks. Note to self: type each chapter's questions [of the book Stuart Little] in order to avoid frustration and anxiety, mine and the students. (from Research Journal, April $18,2005)$

Here, Lynsey decided to conduct more review work, based upon writing samples within students' portfolios:

Today the students answered their comprehension questions and completed a vocabulary assignment. We also completed a mini-lesson on how to look words up in the dictionary. [Based upon these completed assignments attached to the portfolio], more skills review and teaching is required in this area. (from Research Journal, April 19, 2005)

In this final extract, Lynsey shapes her curriculum based upon portfolios and student feedback:

Maybe I should give up having the students complete vocabulary assignments. These assignments seem to trigger frustration in some students. The students say they are not able to find words in the dictionary. I think that they need more practice within this area. In fact, I just convinced myself of the importance of my students having dictionary skills. I will continue with these assignments. (from Research Journal, May 5, 2005) 
So, the portfolios served as a record of student achievement and progress and allowed Lynsey to shape her instruction and curriculum daily/weekly.

At this time, we reiterate our two research questions: (1) From a classroom teacher's point of view, how efficient are portfolios? (i.e., are they time-consuming? or timely?); (2a) would students with disabilities/exceptionalities report experiencing positive aspects of their portfolios? and (2b) how might they reflect upon learning activities within their own portfolios? We structure the results around our queries, beginning with the teacher's viewpoint.

\title{
Portfolios in the Classroom: The Teacher's View
}

In her research journal and final reflection document, Lynsey observed that students exercised choice, displayed pride and ownership over their portfolios, and worked hard on certain projects. In short, Lynsey noticed many of the positive aspects associated with portfolio construction reported in the literature. Although these findings are not unexpected, on a personal note, we found it heartening to watch at-risk students take satisfaction in their own work.

Lynsey wrote that portfolios were "flexible, the students were able to make own decisions in regard to their portfolio assignments. Lots of student choice, with teacher guidance" (Final Reflection Document, June 30, 2005). In addition to choosing preferred artifacts, students decorated their portfolios, which were coil-bound with their pictures on the title page. The personal construction seemed to instill a sense of "pride and ownership. These are the students' own portfolios, they complete[d] the assignments independently and then put together their portfolios on their own" (Final Reflection Document, June 30, 2005). Lynsey noted that some students not only felt pleased with their work, but also that they appeared to be having fun:

\begin{abstract}
Today we finished our bar graphs, which indicated which animals the students in the classroom would want as pets. The finishing touches included colouring the bars, labelling the graph, and writing the title at the top. The students were proud of their accomplishments and how hard they worked, and I heard comments from them such as, "This is cool," "I never knew I could do this," and "Can we do this again?" (from Research Journal, May 11, 2005)
\end{abstract}

Issues of choice, pride, and sense of ownership each resonate with the positive possibility of student self-advocacy. Moreover, that some students expressed aspects of self-efficacy with parts of their portfolios (e.g., "I never knew I could do this") is promising, to be sure. Relatedly, Lynsey recorded that students really worked intensely at certain activities that were to be included in their portfolios:

Today I finally gave the students the assignment from May $4^{\text {th }}$. The assignment was to create a pamphlet that contained facts on mice. I gave the students a fact sheet that they could then pick five facts from and then put these facts on the pamphlet. The students were also told to add lots of colour. This assignment took two classes to finish. I was surprised at the amount of effort that the students put into this assignment. Their finished work is attached into their portfolios. (from Research Journal, May 13, 2005)

As much as we found many encouraging aspects about using portfolios in the classroom, Lynsey did report several times in her research journal that the process was time-consuming: 
Tomorrow I am meeting with Scott [first author], and want the portfolios to be up to date as possible. I am going to mention to Scott that the portfolios are too time consuming to continue, and hope that he will agree with me. (from Research Journal, June 16, 2005)

As we outlined in the literature review, the time-consuming nature of using portfolios is well documented, although, as explained in the discussion section, we posit another reason why this may have been so in our study. We now turn to the students' responses and consider our second research question.

\section{Portfolios in the Classroom: The Students' Views}

We begin with student descriptions of what they learned, based upon the artifacts within their portfolios. In this way, we attempt to give the reader a sense of the activities from the students' perspective. We then present the challenges students reported facing; next we detail areas in which students state improvement, including how they believe they did so. Finally, we present learners' reflections upon their feelings about the use of portfolios. We had anticipated responses would be generally upbeat and ideally related to the kinds of positive qualities around the use of portfolios that the teacher reported (i.e., pride, fun, choice, sense of ownership, effort)—positive issues. Students were more varied in their reactions than was the teacher-not all of them were as optimistic as was Lynsey.

Students' learning: "Some mice don't have any hair at all." To commence the interviews, students were asked what they learned. Probably because their portfolios were in front of them, some provided a mini-tour of things they had done, such as Celeste, "We did poems and we made Stuart Little houses, and we made a nursery rhyme, and we made mouse reports and a graph." Others began by describing the novel, the conceptual hub for the portfolio; Leslie began, "He [Stuart Little] could do lots of things...climb up stuff, find small things." With some verbal prompting where the interviewer provided concrete examples to the initial question, most students described in further detail things they learned; some identified selected bits of declarative knowledge, such as Barry who confirmed that "the female mouse is called a doe, the male mouse is a buck, and Mickey Mouse was born in 1928." Celeste reported that "mice like to eat grass and some live in trees and mice are attracted to peanut butter, and mice live in houses and garages and they're all different colours, and their tail is as long as them." Aaron who, when asked, "What was the most interesting thing you learnt?" answered, "that some mice don't have any hair at all." Notably, several students mentioned some procedural knowledge they had acquired, things that they learned to do. Tim's response to the opening question was "typing letters on the computer...making a Stuart Little house and typing it on the computer." Aaron, stated, "[I learned] how to do "vocabs' and I learned how to make graphs." Many stated they learned to use the computer, to compose a report, and how to use the dictionary; refreshingly, students did not only identify "useful" things (those they might surmise that the interviewer might want to hear). Students mentioned some of the arts-based assignments as well, such as Colin who stated:

I learned how to make a house for him using Popsicle sticks and tape and stuff I brought from home, a container, and a pillow, and a sleeping bag. I made Stuart Little out of a few beads and a pipe cleaner. I made one of his friends out of a ticket and some beads and a clothespin. 
Students' challenges: "Typing up and making the mouse report." Although we were interested in areas students reported learning, we wanted to know about their thoughts around specific aspects of learning such as challenges. The interviewer asked students, "What did you find the hardest/most difficult to do?" Although these portfolios were not exclusively language arts activities, most students limited their discussion to those areas, and most students mentioned examples of procedural knowledge as challenging, such as constructing proper sentences, writing more sentences, using the dictionary, and typing (using the computer). Students also reported difficulty learning new words.

Frequently, students mentioned writing as difficult and without hesitation. The interviewer asked Celeste, "Thinking about your whole project, did you have any difficulty with any of it?" to which she replied, "The proper sentences I did... [and] the vocabulary...because you had to find all these words in the dictionary and they were hard." The teaching assistant asked Barry about challenges; she was not able to finish her question, "Anything you had a hard time with? Did-" before he replied, "like my sentences." Although most students described challenges at the sentence level, Colin noted that the hardest thing for him to do was "Typing up and making the mouse report." In other words, constructing the entire write-up presented a challenge for Colin - possibly not surprising since, as noted by Lynsey,

This was the first time that many students had used a word processing type program. The students were taught how to indent, space and align their paragraphs...[The TA's] helped each student write a paragraph, edit their paragraphs, and then type their paragraph on the computer. (from Research Journal, April 26, 2005)

Equally as often, students indicated that vocabulary was difficult. The interviewer asked Tim, "Did you have a hard time with anything in this project, at the beginning?" Given that the entire portfolio was conceptually organized around the novel, Tim's response seemed a little amusing "only with the Stuart Little stuff." The interviewer probed, "What stuff?" "The questions and the vocab[ulary]," replied Tim. By "vocabulary" some students appeared to suggest that accessing particular words in the dictionary was a challenge, such as Leslie "finding the words," and Karl "finding the answers on what the things are." Aaron's response was less defined: "I found the vocabulary very difficult." Other students seemed to imply that comprehension was difficult. Tim, for example, put together the notions of vocabulary and reading, although most students seemed not to articulate the relationship between using the dictionary and learning new words. There was no interview question that we posed for students to think about which activities seemed easy-perhaps an oversight; however, Celeste commented that typing her report on the computer was "easy." Tim stated, "drawing pictures of Stuart Little...and making Stuart Little's house were easier [than writing and learning new vocabulary words]."

Students' improvements: "I got better at getting the vocabularies right now, looking in the dictionary." Although students reported challenges with writing complete sentences, using the dictionary, using the computer, and learning new words, generally students mentioned aspects of writing and using the dictionary as areas of improvement. Colin's responses were typical:

Interviewer: What can you do better now that you've done this project? What have you improved on? Colin: I'm writing better.

Interviewer: You write better? How so? 
Colin: (pause).

Interviewer: So which way do you mean you write better, your sentences or your spelling or -how do you-

Colin: My sentences.

When Celeste was asked, "Okay. Now what did you improve on?" she replied, "Proper sentences." Similarly, Barry commented, "Complete sentences;" the interviewer confirmed, "So you had a hard time with your sentences and then?" Barry stated, "[I] got better at them." Barry then defined a complete sentence, "You need...a capital and a period at the end...or a question mark or an exclamation mark." Karl provided an example of an incomplete sentence, "Like things aren't complete sentences, like 'Because he did not like Stuart' and that didn't make sense [that is not a complete sentence]." Karl then proceeded to demonstrate a complete sentence: "Snowbell [the family cat] did not tell the Littles about Stuart [getting caught] in the blinds by accident, because he [Snowbell] did not like him [Stuart Little]."

Many students stated that they improved their vocabulary, as noted in the previous section. Some students seemed to use the word vocabulary to imply better dictionary use:

Interviewer: And did you notice that you improved on anything?

Aaron: Yeah, with one thing.

Interviewer: What did you improve on?

Aaron: Vocabulary.

Interviewer: What was hard about it?

Aaron: Looking up all the words in the dictionary.

Interviewer: Okay. And now?

Aaron: It's easier for me.

Leslie seemed to use vocabulary in the same way. At the end of the following excerpt, the interviewer attempted to get Leslie to think about the purpose of learning new words:

Interviewer: What do you think you did the best on, that you actually improved, you got better at

doing?

Leslie: I got better at getting the vocabularies right now, looking in the dictionary.

Interviewer: Oh. So what did you used to do before you started Stuart Little?

Leslie: We used to learn about the rabbit.

Interviewer: Oh, okay. But, no, I mean in terms of the dictionary.

Leslie: I used to get lots of help.

Interviewer: Oh, okay. And now?

Leslie: Now I could just grab a dictionary and look for the same word.

Interviewer: What did the vocabulary help you do?

Leslie: We have to do, learn about Stuart.

Interviewer: Okay. So you learn about words in the novel.

The interviewer asked students to respond around areas of improvement, but also how they "got better at getting the vocabularies" as well as how they got better writing. Salend (1998) suggested concrete queries to help students think about strategies they used to progress. Some students reported that practice and feedback allowed them to write and read more effectively. Barry, for example, when asked how he got better at writing sentences replied, "by keep writing them," while Tim said that "getting used to ...[the] Stuart Little vocab[ulary improved my] reading." When asked, "Why do you think that you got better at doing it [writing sentences]?" Celeste reflected, "because they were getting corrected and I had to sometimes do them over, so I was kinda getting the point." To which the interviewer confirmed, "Oh, Okay? So, basically just 
kept practicing at it?" "Yeah," said Celeste.

As mentioned, part of the study's purpose was to see if students experienced positive aspects of portfolio development. So far, most students expressed at least some areas of challenge and improvement, and some of them indicated how they improved. There is some evidence then of student self-efficacy and self-knowledge through the use of portfolios, although the evidence speaking to the positive nature of portfolios seems not as thick as we had hoped. We deliberate why this may be the case in the discussion section.

Students' feelings: "[l feel] happy... because it's fun." Finally, the interviewer asked students how they felt about their portfolios. Some students replied immediately and buoyantly. Barry commented that constructing his portfolio "was fun;" Leslie said she was "happy...because it's [making a portfolio] fun." Not all students were so enthusiastic; responses varied, although most mentioned at least one artifact, aspect, or feature in an affirmative or positive way. Significantly, many students referred to making proper sentences and using the dictionary, areas in which several students reported improvement, as sources of positive feelings:

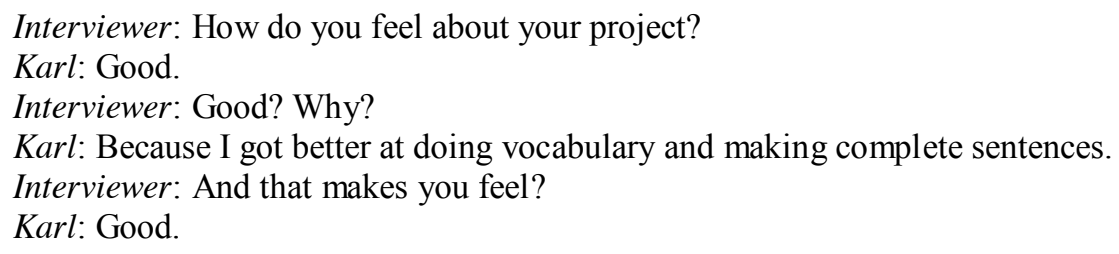

The finding that positive feelings tended to occur around areas of progress was encouraging. There were exceptions, however. Barry, for example, did not mention art projects as an area of improvement (or of challenge for that matter), although he did report art as a source of satisfaction:

Interviewer: What do you think you did really well at? What do you think is the best thing you did with your portfolio?

Barry: Pictures.

Interviewer: ...Yes, you're quite the artist, aren't you?

Tim too mentioned that he enjoyed constructing art:

Interviewer: Okay. So how do you feel about the work that you did?

Tim: Pretty good.

Interviewer: Good. What makes you feel good?

Tim: The work.

Interviewer: What work? What work did you do that makes you feel good?

Tim: The pictures and Stuart Little's house.

When asked what made him feel proud about his portfolio, Colin indicated simply finishing the project. Perhaps for some students with ADHD, for which Colin was being screened, or for students whose lives can be chaotic, changing, and maybe unstable due to life circumstance, a sense of completion may be important:

Interviewer: What makes you feel proud [about this project]?

Colin: That I got my book done.

Interviewer: Oh, that you completed it?

Colin: Yeah. 
Some students appeared a little unsure about their feelings altogether, such as Aaron, although with prompting he was able to talk about some specific things he accomplished about which he felt good:

Interviewer: What makes you feel good about what you did?

Aaron: Nothing [pause] Mmhmm.

Interviewer: Okay. Is there one thing that you really liked that you did, that you thought you did really well at?

Aaron: Around mice facts, the fun facts on mice.

Interviewer: The fun facts on mice, your report?

Aaron: Yeah.

Aaron's home situation was quite unstable during this time, which may have contributed to an overall sense of uncertainty. Similarly, when asked, "How do you feel about...completing it [the portfolio]?" Celeste replied, "I don't know," although given her diagnosis of PTSD this may not have been surprising (see Table 1).

To conclude this section, many students were able to describe some aspects of what they had learned, areas of difficulty, and improvement. A few were able to discuss how they improved. In terms of describing the process of constructing and reflecting upon their portfolios in positive ways, some students did and some did not. Next, we will discuss some implications of our findings within our two research questions.

\section{Discussion and Conclusion}

\section{Portfolio Efficiency: Artefacts as Object d'Arts vs. Objects for Reflection}

We begin by thinking through some issues related to our first research query. As detailed in the introduction, many researchers, particularly practitioners, claim that portfolios in the classroom can be time-consuming and laborious; we concur. As an aside, although students were asked what they found challenging or most difficult about their portfolios none mentioned workload or amount of time. Indeed, Lynsey recorded this frustration almost verbatim on May 3, 2007, "portfolios...seem to be extremely time-consuming." Of course, it is possible that we found what we knew to be the case; however, after we gave this some thought, there may be at least one unexpected reason that may account for the excessive time required-surprising to us at least. We may have been inadvertently placing too much emphasis on portfolio appearance - on creating objets d'art, rather than portfolio function. Quite likely, we emphasized the portfolio as a showcase or platform, attempting to display students' exemplary works (Carothers \& Taylor, 2003; Duffy et al., 1999), rather than the portfolio as a reflective vehicle (Salend, 1998). In the following excerpt from her research journal, for example, Lynsey laments the disproportionate time seemingly required, while simultaneously adding work (thereby increasing the time) simply to have enough artifacts:

Today I gave the students time to "catch-up" on any missed portfolio assignments or any missed notebook assignments (questions and vocabulary)...I want to finish reading the novel with the class and I want the class to work on comprehension questions. But, it seems that the extra assignments that I was having the students complete is too much. (from Research Journal, June 16, 2005) 
In an earlier entry, Lynsey even wondered whether her students were able to produce enough work in a timely fashion for their portfolios:

Today the students read chapter three in Stuart Little. It seems to me that this novel is taking a very long time. Portfolio[s]...seem to be extremely time consuming. I wonder if this is because of my students. They maybe lack the ability to complete an assignment in one day. They are easily frustrated and therefore the pace of each lesson and class seem to be slower and more individualized. (from Research Journal, May 3, 2005)

Certainly, Lynsey is most committed to students who learn differently, at different rates and ways, so the above quote should be understood as emanating more from our frustration with portfolio process shortcomings rather than the students. In short, we may have let the performative aspect of portfolios over-determine how we implemented them. Creating exemplary work often takes longer and is more time-intensive than work produced as a matter of course throughout daily classroom routines. It is possible that the portfolio with its roots in the fine arts may have had an almost unknowing appeal to present students' ideal work. Another reason we suggest that portfolios may have been time demanding - one that was not surprising to us - has to do with the perpetually changing classroom enrollment. As the first author observed, on a daily basis there appeared to be many demands placed upon the teacher. Given the fluctuating nature of classroom membership any research within this environment would be difficult to complete.

Final thoughts on efficiency. Our findings reiterate the need to be clear as to the reasons why and how portfolios may be used. We agree with Cole et al. (1997) and Kleinert et al. (2002) who address labour-intensity head on: connect instructional strategies to portfolios, link portfolios to IEP, create SMART (Specific, Measurable, Achievable, Relevant and Timely) goals and outcome rubrics, and involve students in creating and maintaining their portfolios. Kleinert et al. demonstrated how teachers can set up elements of student planning, self-monitoring, and self-evaluation within their instruction. Essentially, student-constructed artifacts become the portfolio. To link portfolios to IEP's teachers and students must arrange for learning artifacts to be collected within the specific goals and objectives. It is within IEP planning and student-led meetings that portfolios may be most useful and time efficient (see Young et al., 1997). In short, had we been clearer about the purpose of our portfolio project, we likely could have been more time and labour efficient. We now turn to the discussions around our second research question about whether students with disabilities/exceptionalities would report positive aspects often associated with portfolios.

\section{Portfolios and Positive Possibilities}

From the teacher's perspective, using portfolios provided some positive benefits for learners: Lynsey felt that students worked harder on certain portfolio assignments and actively chose particular artifacts to go into their portfolios, which may have contributed to a sense of ownership and pride. Some students indicated to Lynsey and to the research interviewer that using portfolios was fun. When interviewed, some students reported feelings of satisfaction regarding their portfolios. Moreover, most students reported feeling good about the areas of improvement that they identified-mostly language arts activities. It may be obvious that the elementary students with disabilities/exceptionalities used a different language than did the 
teacher to describe the positive and encouraging aspects of portfolios. Students used words like "fun," "happy," and "good" to describe their feelings about their portfolios, while the teacher used phrases such as pride and ownership, student effort, and student choice. Although the students' and teacher's words may not describe the exact same thing, it seems reasonable that there is enough of an overlap to suggest that some of these students did find aspects of creating their own portfolios as positive. We reiterate that most students tended to feel good about areas which they found challenging, but in which they also progressed (e.g., writing and the comprehension skill, using the dictionary).

Incidentally, in the interviews no student talked about numeracy as an area of improvement or of satisfaction, although the teacher did, referring to the frequency bar graphs. It may be that the teacher's perspective was different than her students in this regard, perhaps more global in her appreciation of all the ways that her students advanced. It may be that the students simply did not think of bar graphs within the interviews. Within schools, reading and writing literacies may often be unintentionally privileged over numeracies. Alternatively, completing the graphs took little time as compared to writing reports, so most students experienced an immediate sense of finishing this activity as compared to most other activities.

Final thoughts on positive possibilities. Although students were asked to respond to questions about how they improved, the interviewer may have used too general a query to elicit information around specific strategies. Salend (1998), for example, suggested concrete queries to help students think about specific strategies employed, such as "This item reveals my improvement in . Before, I used to . However, now I ." and "In working on this item, I used the following method: . The steps I used were , and "(p. 40). In retrospect, our research team should have discussed how to scaffold questions and provided examples of strategies for students to reflect upon. Also, our students likely did not have the vocabulary to talk in specific terms about how they improved. It would indeed be positive for students to be able to identify how they improved, a skill that is metacognitive in nature. There is a difference between asking students to reflect upon their learning, and teaching them to do so like Cole et al. (1997) did. These researchers proposed a Cognitive Model for Assessing Portfolios, a framework through which educators employ a kind of metacognitive instruction to teach students to identify rationale, goals, content, and evaluative techniques of their portfolios. Still and all, a few of our students stated that they were able to improve through practice and feedback.

In the future, we might narrow our research focus to teaching metacognition within the portfolios for students with disabilities/exceptionalities (see Israel, Bauserman, \& Block, 2005). In other words, we could model and teach a metacognitve language to students with disabilities/exceptionalities. We may also introduce portfolios earlier in the year and interview students more often "Maybe [the research project] would have run more smoothly if students were more familiar with portfolios" (from Lynsey's Final Reflection Document, June 30, 2005). More frequent interviewing may allow students to practice structured reflectivity.

\section{References}

Agosta, E., Graetz, J., Mastropieri, M., \& Scruggs, T. (2004). Teacher-researcher partnerships to improve social behaviours through social stories. Intervention in School and Clinic, 39(5), 276-287. 
Babkie, A. M., \& Provost, M. C. (2004). Teachers as researchers. Intervention in School and Clinic, 39 (5), 260-268.

Battle, D., Dickens-Wright, L., \& Murphy, S. (1998). How to empower adolescents: Guidelines for effective self-advocacy. Teaching Exceptional Children, 30, 28-33.

Carothers, D., \& Taylor, R. (2003). The use of portfolios for students with autism. Focus on Autism and Other Developmental Disabilities, 18(2), 125-128.

Carpenter-Aeby, T., \& Kurtz , D. (2000). The portfolio as a strengths-based intervention to empower chronically disruptive students in an alternative school. Children \& Schools, 22(4), 217-231.

Cole, K. B., Struyk, L. R., Kinder, D., Sheehan, J. K., \& Kish, C. K. (1997). Portfolio assessment: Challenges in secondary education. The High School Journal, 80(4), 261-272.

Daniels, V. I. (1999). The assessment maze: Making instructional decisions about alternative assessments for student with disabilities. Preventing School Failure, 43(4), 171-178.

Denham A., \& Lahm, E. A. (2001). Using technology to construct alternate portfolios of students with moderate and severe disabilities. Teaching Exceptional Children, 33(5), 10-17.

Duffy, M., Jones, J., \& Thomas, S. (1999). Using portfolios to foster independent thinking. Intervention in School and Clinic, 35(1), 34-37.

Ezell, D., \& Klein, C. (2003). Impact of portfolio assessment on locus of control of students with and without disabilities. Education and Training in Developmental Disabilities, 38(2), 220-228.

Ezell, D., Klein, C., \& Ezell-Powell, S. (1999). Empowering students with mental retardation through portfolio assessment: A tool for fostering self-determination skills. Education and Training in Mental Retardation, 34(4), 453-463.

Farr, R. (2003). Building useful instructional reading assessments. New England Reading Association Journal, 39(1), 1-8.

Gelfer, J. I., \& Perkins, P. G. (1998). Portfolios: Focus on young children. Teaching Exceptional Children, 31(2), 44-48.

Ghesquière, P., Maes, B., \& Vandenberghe, R. (2004). The usefulness of qualitative case studies on special needs education. International Journal of Disability, Development and Education, 51(2), 171-184.

Hager, K. D., \& Slocum, T. A. (2005). Using alternate assessment to improve educational outcomes. $R u$ ral Special Education Quarterly, 24(1), 54-59.

Hardin, D., \& Cook, H. (2001). Cross-curricular portfolios: Time well spent. Principal Leadership, 1(6), 24-27.

Israel, S. E., Bauserman, K. L., \& Block, C. C. (2005). Metacognitive assessment strategies. Thinking Classroom, 6(2), 21-28.

Kampfer, S. H., Horvath, L. S., \& Kleinert, H. (2001). Teachers' perceptions of one state's alternate assessment: Implications for practice and preparation. Exceptional Children, 67(3), 361-374.

Kleinert, H., Green, P., Hurte, M., Clayton, J., \& Oetinger, C. (2002). Creating and using meaningful a1ternate assessments. Teaching Exceptional Children, 34(4), 40-47.

Kleinert, H., Kearns, J., Farmer, J., \& Kennedy, S. (1997). Accountability for all students: Kentucky's alternate portfolio assessment for students with moderate and severe cognitive disabilities. The Journal of the Association for Persons with Severe Handicaps, 22, 88-101.

Kleinert, H., Kennedy, S., Kearns, J., \& Farmer, J. (1999). The impact of alternate assessments: A statewide teacher survey. The Journal of Special Education, 33(2), 93-102.

Manning-Kratcoski, A. (1998). Guidelines for using portfolios in assessment and evaluation. Language, Speech \& Hearing Services in Schools, 29(1), 3.

McCormick, B. (2000). Case study research in therapeutic recreation. Therapeutic Recreation Journal, 34(3), 245-252.

Merriam, S. (1998). Qualitative research and case study applications in education. San Francisco: Jossey-Bass Publishers. 
Salend, S. (1998). Using portfolios to assess student performance. Teaching Exceptional Children, 31(2), 36-43.

Salvia, J., Ysseldyke, J., \& Bolt, S. (2006). Assessment in special and inclusive education (10th ed.). Boston: Houghton Mifflin Company.

Stake, R. (1995). The art of case study research. Thousand Oaks, CA: Sage Publications.

Stalker, K. (1998). Some ethical and methodological issues in research with people with learning difficulties. Disability \& Society, 13, 5-19.

Swain, J., Heyman, B., \& Gillman, M. (1998). Public research, private concerns: Ethical issues in the use of open-ended interviews with people who have learning difficulties. Disability \& Society, 13, 21 36.

Thompson, S. A. (2002). My research friend? My friend the researcher? Mis/informed consent and persons with developmental disabilities. In W. van den Hoonaard (Ed.), Walking the tightrope: Ethical issues for qualitative researchers (pp. 95-106). Toronto, ON: University of Toronto Press.

Thompson, S. A. (2007). Linking portfolio assessment to self-advocacy. In L. Bullock, V. Heung, \& L. Aylward (Eds.), Proceedings of the Tenth Biennial Conference of the International Association of Special Education (pp. 79-82). The University of Hong Kong, Hong Kong, China.

Walter-Thomas, C., \& Brownell, M. T. (2001). An interview with Bonnie Jones: Using student portfolios effectively. Intervention in School and Clinic, 36(4), 225-229.

Watson-Barnett, J. (1997). A qualitative study of first-grade student reflections during the portfolio evaluation process. Unpublished doctoral dissertation, University of Denver, Colorado.

White, E. B. (1945/1973). Stuart Little. New York: Harper Collins Publishers, Inc.

Yin, R. (1994). Case study research: Design and methods (2nd ed.). Thousand Oaks, CA: Sage Publications.

Young, J., Mathews, S., Kietzmann, A., \& Westerfield, T. (1997). Getting disenchanted adolescents to participate in school literacy activities: Portfolio conferences. Journal of Adolescent \& Adult Literacy, 40(5), 348-360.

Ysseldyke, J., \& Olsen, K. (1999). Putting alternative assessments into practice: What to measure and possible sources of data. Exceptional Children, 65(2), 175-185.

\section{Authors' Note}

Correspondence concerning this article should be addressed to S. Anthony Thompson, Faculty of Education, University of Regina, 3737 Wascana Parkway, Regina, Saskatchewan, Canada, S4S 0A2. E-mail: Santhony.Thompson@uregina.ca.

Versions of this paper were presented at WestCAST Conference (Western Canadian Association for Student Teachers; February 2007), Winnipeg, MB, Canada and at the $10^{\text {th }}$ Biennial International Conference on Special Education, The University of Hong Kong, Hong Kong, HK (June 2007).

We gratefully acknowledge funding received from the Saskatchewan Instructional Development \& Research Unit (SIDRU) at the University of Regina for this research. We also thank the Regina Catholic School Board for supporting this project; Louana Prudat and Trisha Matyas, two teaching assistants who participated in this research; and Miranda Davidson for acting as a research assistant. The first author would also like to thank members of the Academic Writer's Circle in the Faculty of Education at the University of Regina for their advice and support. We would also like to thank the reviewers and editor of this journal for their helpful advice. 